\title{
Globalization, Resistance to Economic
}

Ruth Buchanan

Osgoode Hall Law School of York University, rbuchanan@osgoode.yorku.ca

Source Publication:

Encyclopedia of Law and Society, American and Global Perspectives. Sage Publishing, 2007.

Follow this and additional works at: https://digitalcommons.osgoode.yorku.ca/scholarly_works

Part of the Law Commons

\section{Recommended Citation}

Buchanan, Ruth. "Globalization: Resistance to Economic." Clark, David Scott, ed. Encyclopedia of Law and Society, American and Global Perspectives. Sage Publishing, 2007. p. 665-667. ISBN: 9780761923879

This Book Chapter is brought to you for free and open access by the Faculty Scholarship at Osgoode Digital Commons. It has been accepted for inclusion in Articles \& Book Chapters by an authorized administrator of Osgoode Digital Commons. 


\section{Globalization, Resistance}

TO ECONOMIC

Popular resistance to economic globalization, while a phenomenon of long-standing duration in the global South, has only recently become a phenomenon of note in the northern hemisphere. The antiglobalization movement-or the movement for global social justice, as some activists would prefer to call it-became well known as a consequence of a series 
of large public protests of transnational economic policies and institutions. These included protests that accompanied the Ministerial Conference of the World Trade Organization (WTO) in Seattle (1999), meetings of the World Bank and the International Monetary Fund (IMF) in Washington, D.C. (2000) and in Prague (2000), the G-8 (Group of 8) Meeting in Genoa (2001), and the Summit of the Americas in Quebec City (2001).

While events such as these have important symbolic value for some in the movement, they represent only a small part of a phenomenon of much greater scope and duration. Globally, the dramatic growth of civil society organizations over the past several decades, including local, regional, and transnational groups and networks among them, has provided the foundation on which the movement to resist economic globalization has been built.

\section{Protests against Globalization}

Social movements in the developing world have been mounting numerous large-scale public protests of the neoliberal economic reforms called for by the socalled Washington Consensus policies of the World Bank and IMF for several decades. Such protests, frequently of a scale much larger than comparable events in the North, have continued with very little media or public attention in the North.

Between November 27 and December 3, 1999, large protests were mounted during a Ministerial meeting of the World Trade Organization. More than 700 organizations and between 40,000 and 60,000 people took part in the protests against the WTO. The demonstrators and activists were successful in disrupting the meeting, but the protests were marked with violence and police brutality. However, the event was highly successful in drawing the Western world's attention to the policies of the WTO and their consequences for workers, communities, and the environment. "Our World Is Not For Sale" (OWINFS) is a transnational network of activists and organizations that emerged from this event. Smaller scale protests, mobilizations, and teach-ins have been held in conjunction with subsequent WTO Ministerial meetings at Doha, Qatar, in 2001 and at Cancun, Mexico, in 2003.
An organized movement against the Free Trade Area of the Americas (FTAA) began with a People's Summit held in Santiago, Chile, in 1998. The Second People's Summit of the Americas was held in Quebec City in April 2001 as political leaders sought to negotiate a free trade agreement for the Americas. The People's Summit called upon the leaders to renounce neoliberal globalization and to allow social, environmental, human rights, and other nonmarket interests to take precedence over the goal of trade liberalization. The Quebec Summit was accompanied by several days of highly visible and publicized street marches, protests, and confrontations with police. People's Summits, representing very significant mobilizations of civil society organizations from throughout the hemisphere, were also organized in conjunction with subsequent FTAA meetings in Quito (2002) and Miami (2003). In Miami, a very significant police presence kept public protests to a minimum.

In July 2001, over 200,000 people from around the world gathered in Genoa, Italy, to express their rejection of the "capitalist agenda" of the leaders of the G-8 Nations. The meetings were conducted under very tight security, while outside, the highly policed streets of Genoa were witness to sometimes violent confrontations that left a twenty-three-year-old protester dead, several others injured, and many more jailed. Since the events in Genoa, some groups have argued for a retreat from the large-scale public protest, which when met with heavy-handed policing can lead to violence, in favor of other, nonviolent methods of mobilization and public education.

\section{Global Civil Society and the World Social Forum}

"Global civil society" has emerged in recent decades as an important force for change in international economic governance. Global civil society includes a very wide range of actors and organizations, from grassroots groups focused on popular education and local projects to transnational organizations (such as Oxfam) seeking to lobby governments and international institutions for policy changes at the highest 
levels. It includes both relatively more organized transnational networks of nongovernmental organizations (NGOs) and advocacy organizations to relatively less organized social movements, citizens groups, and student activist networks. Ideologies span a spectrum from "reformers," who advocate gradual transformation within the existing frameworks through legal reform and mechanisms of representative democracy, to "revolutionaries," who totally reject the existing institutional frameworks of neoliberalism, including the World Bank and the WTO. A commitment that unites most of these actors, however, is the development of alternatives to currently dominant models of global governance, such as support for local, sustainable agriculture, environmental protection, and local community development. One important site for the debate and development of these ideas has been the World Social Forum (WSF).

The WSF, held each year to coincide with the influential World Economic Forum, is a "space" that challenges the rejection of alternatives by neoliberalism and affirms the possibility of what Boaventura de Sousa Santos referred to as "counter-hegemonic globalization." It rejects the market-driven models of globalization advanced by world leaders, and at the same time contests as imperialist transnational economic institutions that impose such models on less developed countries of the South.

Commencing in 2001 in Porto Alegre, Brazil, organized by a network of Brazilian and European NGOs, the WSF by its fourth meeting in 2004 had become a truly global meeting attended by representatives from more than 140 countries. The WSF has evolved to encompass regional social forums in many parts of the world. Critics of the forum see it as replicating the very notion of exclusion that it seeks to challenge, as the inability of many grassroots activists from the South to attend due to lack of funds denies them the very voice that the forum's existence is predicated upon. The decision to hold the fourth WSF meeting in India was partly motivated by this concern. Notwithstanding these perhaps inevitable challenges of inclusiveness and participation, the WSF is a unique new political formation, a progressive "movement of movements" that goes beyond merely critiquing global governance structures to embrace the difficult task of building alternatives.

\section{-Ruth Buchanan}

See also Globalization, Governance, and Democratic Participation; Globalization, Nongovernmental; Globalization, Processes of Legislative; Globalization and Law in Everyday Life; Markets; Nongovernmental Organizations

\section{Further Readings}

Anheier, Helmut, Marlies Glasius, and Mary Kaldor, eds. (2001). Global Civil Society Yearbook 2001. New York: Oxford University Press.

Brecker, Jeremy, Tim Costello, and Brendan Smith, eds. (2002). Globalization from Below: The Power of Solidarity. Boston: South End Press.

Hardt, Michael, and Antonio Negri. (2004). Multitude: War and Democracy in the Age of Empire. Cambridge, MA: Harvard University Press.

International Forum on Globalization. (2004). Alternatives to Economic Globalization: A Better World is Possible. San Francisco: Berrett-Koehler.

O'Brien, Robert, Anne Marie Goetz, Jan Aart Scholte, and Marc Williams. (2000). Contesting Global Governance: Multilateral Economic Institutions and Global Social Movements. Cambridge: Cambridge University Press.

Our World Is Not For Sale (2006). "Home Page." http:// www.ourworldisnotforsale.org/about.asp.

Polet, Francois, and CETRI, eds. (2004). Globalizing Resistance: The State of Struggle. London: Pluto Press.

Santos, Boaventura de Sousa, and Cezar Rodriguez-Gavarito, eds. (2005). Law and Couter-hegemonic Globalization: Toward a Cosmopolitan Legality. Cambridge: Cambridge University Press.

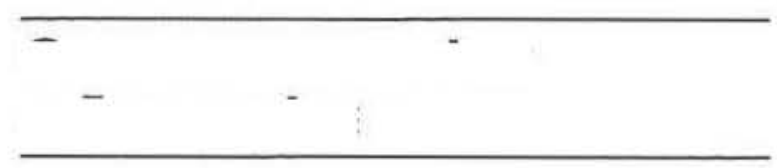

